\title{
Renal fibromuscular dysplasia
}

\author{
Joel Woodley-Cook, ${ }^{1}$ Magdalena Konieczny, ${ }^{1}$ Graham Roche-Nagle ${ }^{2}$
}

'Department of Medical Imaging, University of Toronto, Toronto, Ontario, Canada ${ }^{2}$ Toronto General Hospital, Toronto, Ontario, Canada

\section{Correspondence to}

Dr Graham Roche-Nagle, graham.roche-nagle@uhn.ca

Accepted 5 September 2015

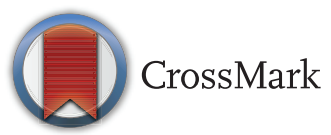

To cite: Woodley-Cook J, Konieczny M, RocheNagle G. BMJ Case Rep Published online: [please include Day Month Year] doi:10.1136/bcr-2015211973

\section{DESCRIPTION}

A 35-year-old woman was diagnosed with hypertension refractory to three antihypertensive medications. There was a suspicion for renovascular hypertension, and a contrast-enhanced CT scan was performed, which demonstrated alternating sten-

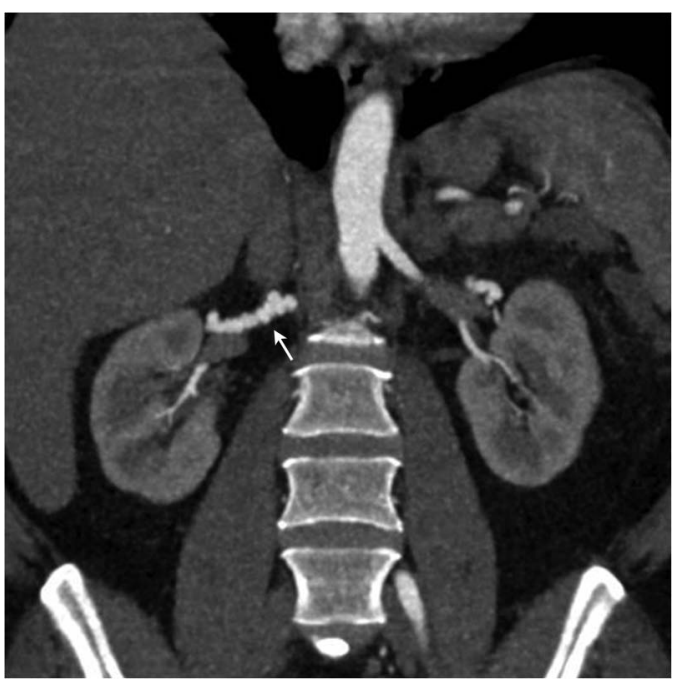

Figure 1 Coronal arterially enhanced CT image demonstrating the alternating stenoses and aneurysmal dilation of the right renal artery (arrow).

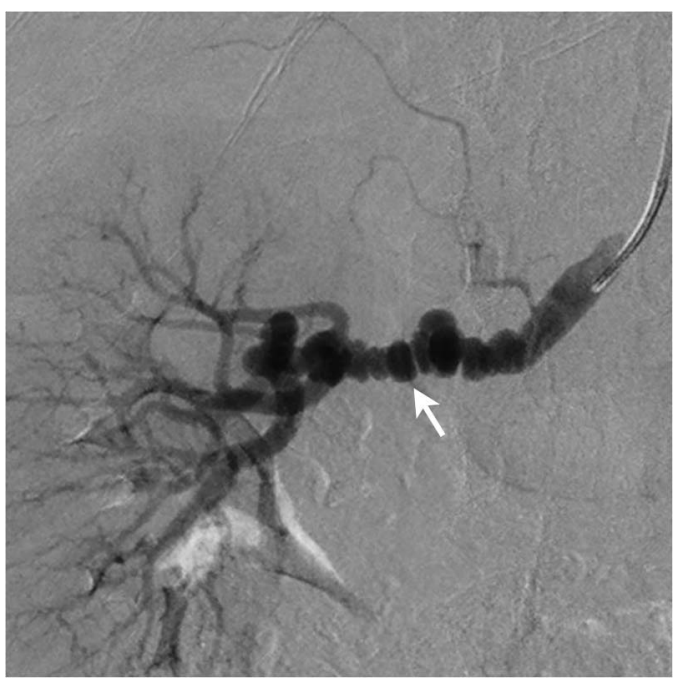

Figure 2 Catheter-directed digital subtraction angiography confirms the 'string of beads' appearance of the right renal artery (arrow). oses and dilations of the patient's bilateral renal arteries (figure 1, arrow showing the right renal artery). This imaging finding represents the classic 'string of beads' appearance of renal artery fibromuscular dysplasia, thought to be the cause of this patient's refractory hypertension. The patient was brought to the angiography suite, where catheterdirected digital subtraction angiography confirmed the CT finding of the 'string of beads' sign of the right renal artery (figure 2, arrow). She underwent percutaneous transluminal balloon angioplasty of her renal arteries, as there was a similar finding of the left renal artery (not shown). At present, 3 months following the procedure, the patient is normotensive on a single oral antihypertensive.

\section{Learning points}

- Renal fibromuscular dysplasia (FMD) is a non-inflammatory, non-atherosclerotic arterial process characterised by segmental collagen deposition and smooth muscle overgrowth within the renal arterial wall, and is an uncommon cause of renovascular hypertension. ${ }^{1}$

- Renal FMD has a propensity to affect females and most commonly presents between 15 and 50 years of age. ${ }^{1-3}$

- The gold standard for diagnosis and treatment of renal FMD is renal arteriography and percutaneous transluminal balloon angioplasty, which is successful in reducing blood pressure in approximately $95 \%$ of cases. $^{2} 3$

Contributors GR-N was the staff surgeon involved with the case. He also edited the report. JW-C was the fellow involved with the case. He wrote the report. MK observed the case, edited the report and created the figures.

Competing interests None declared.

Patient consent Not Obtained.

Provenance and peer review Not commissioned; externally peer reviewed.

\section{REFERENCES}

1 Olin JW, Sealove BA. Diagnosis, management, and future developments of fibromuscular dysplasia. J Vasc Surg 2011:53:826-36.e1.

2 Slovut DP, Olin JW. Fibromuscular dysplasia. N Engl J Med 2004;350:1862-71

3 Baumgartner I, Lerman LO. Renovascular hypertension: screening and modern management. Eur Heart J 2011;32:1590-8. 
Copyright 2015 BMJ Publishing Group. All rights reserved. For permission to reuse any of this content visit http://group.bmj.com/group/rights-licensing/permissions.

BMJ Case Report Fellows may re-use this article for personal use and teaching without any further permission.

Become a Fellow of BMJ Case Reports today and you can:

- Submit as many cases as you like

- Enjoy fast sympathetic peer review and rapid publication of accepted articles

- Access all the published articles

- Re-use any of the published material for personal use and teaching without further permission

For information on Institutional Fellowships contact consortiasales@bmjgroup.com

Visit casereports.bmj.com for more articles like this and to become a Fellow 